O. Snihova, Cand. Sc. (Econ.), Assoc. Prof., orcid.org/0000-0001-7456-4894
Institute for Economics and Forecasting NAS of Ukraine, Kyiv, Ukraine, e-mail: osnigova @ukr.net

\title{
PROSPECTS OF RECOVERY OF EFFICIENT FUNCTIONING OF COAL INDUSTRY IN THE EAST OF UKRAINE
}

Purpose. To find out opportunities and prospects of coal industry recovery at the controlled territories of Donetsk and Luhansk regions in the modern economic and political conditions. To determine the role of this industry in the recovery of the economies of Eastern regions of Ukraine.

Methodology. The goal has been realized based on the application of the following methods: generalization and systemic analysis using complex and interdisciplinary approaches - when external and domestic factors, that form the opportunities, risks and threats of coal industry's functioning in the modern conditions were determined; SWOT analysis - when strengths and weaknesses of coal industry functioning at the controlled territories of Donetsk and Luhansk regions in the new economic and political conditions were estimated.

Findings. Strengths and weaknesses of coal industry of the controlled territories of Donetsk and Luhansk regions have been estimated, the opportunities and threats of its functioning have been determined, the prospects of the coal industry of these regions in the new economic and political conditions have been found out.

Originality. Consists of the determination of capacity and prospects of coal industry of Donetsk and Luhansk regions' recovery in the new economic and political conditions, characterized by the losses of the part of the potentials of Eastern regions and Ukraine's integration into the European energy space.

Practical value. The results of the study can be used by Government institutions in order to form and to realize the concepts, strategies, programs and action plans of the recovery of economy of Eastern regions of Ukraine in the conditions of changing economic, industrial and natural potentials of Donetsk and Luhansk regions.

Keywords: coal industry, recovery prospects, Donetsk and Luhansk regions, risks, possibilities, European energy space

Introduction. The coal industry, being one of the "basic" sectors of Donetsk and Luhansk regions' economy, plays a significant role providing the energy security of Ukraine and supplies the functioning of exportoriented sectors (coke and chemical, metal industries, electric power production). For a long time this sector was in crisis. A number of unregulated legislative problems of restructuring and low manageability of these processes had caused the accumulation and aggravation of socio-economic problems of the sector to the level of threats for the national security of Ukraine. Its further functioning required reforms of this part of energy production sector. However, due to the armed conflict at the East of Ukraine the coal industry has got significant losses, which should be estimated from the position of the opportunities of its recovery and functioning in the new economic and political conditions.

Analysis of the recent research and publications. A significant attention has been devoted to the problems of the effective ways of developing and restructuring the coal industry of Ukraine. Thus, those problems have been widely discussed in the research literature. Among the most elaborated directions there are issues of market relations setting in the coal industry and market infrastructure formation, searching the ways of effective interaction of Government and business in modernization process [1, 2]. Given the significant restructuring history of coal industry of independent Ukraine, weighty are the results of problems solving of depressive mining towns, caused by coal industry reforming [3].

In the recent years the studies have been spread concerning the coal industry problems in the view of the

(C) Snihova O., 2019 involvement of some territories of its positioning into the hybrid war. Just at the beginning of Russian aggression the state of coal industry in these conditions was estimated [4], and energy component of this war of new generation was studied [5]. Also the issues of coal industry functioning have been raised when the priorities of socio-economic potential of Donbas are estimated [6], as well as the problems of rebuilding of destroyed/damaged potential of the sector at the uncontrolled territories after the recovery of control [7].

Unsolved aspects of the problem. However, practically beyond the frame of the scientific studies there stay the estimates of strengths and weaknesses of coal industry of the territories of Donetsk and Luhansk regions controlled by Ukraine, that influence directly the sector's recovery. Weakly studied are the opportunities and risks of its functioning in the new economic and political conditions [8]. And, given the changes in recovery conditions with time, the prospective determination of the recovery of effective coal industry functioning at the controlled territories remains topical and, moreover, requires the establishment of the monitoring by government institutions, especially in the context of its restructuring.

Thus, the objectives of the article are to find out the opportunities and prospects of coal industry recovery at the controlled territories of Donetsk and Luhansk regions in the modern economic and political conditions, to determine the role of this industry in the recovery of the economies of Eastern regions of Ukraine.

Methods. To reach the goal of the study, the estimate of coal industry potential at the territories of Donetsk and Luhansk regions controlled by Ukraine has been performed. Based on generalization and systemic analy- 
sis using complex and interdisciplinary approaches, external and domestic factors that form the opportunities, risks and threats of the coal industry's functioning in the modern conditions have been determined. Using SWOT analysis, the strengths and weaknesses have been estimated, opportunities, risks and threats of coal industry functioning at the controlled territories on Donetsk and Luhansk regions in the new economic and political conditions have been determined.

Results. Before the beginning of the armed conflict, the domestic coal market had comprised two key segments - energetic (appr. $70 \%$ of the total market size) and coke (about $30 \%$ ) coals - and had been characterized by the deficit of coke and abundancy of energetic coals. For now, of 93 coal mines, subordinated to the Ministry of Energy and Coal Industry, $40 \%$ only have been left at the territory controlled by Ukrainian powers, of them: 25 mines operate in coal extraction mode, 12 - in life support mode [9]. At the temporarily uncontrolled territories there are 85 coal mines of all property forms, of them 60 coal mines extract energetic and $25-$ coke coal.

All $100 \%$ of coal mines, extracting anthracite coal (Snizhne, Shakhtarsk, Torez, Rovenky, Sverdlovsk), remain at the territories of the so-called 'Peoples' Republics". However, those, owned by "System Capital Management" Ltd, had been working under the law on Ukraine till the March of 2017. Namely, PJSC "DTEKKomsomolets Donbasu", LLC "DTEK-Sverdlovantratcit" (coal mines "Dovzhanska-Kapitalna", named after Y. M. Sverdlov, "Chervonyi Partyzan”, "Kharkivska", "Tsentrosoiuz"), LLC "DTEK-Rovenkyantratsyt" (coal mines No 81 "Kyivska", named after V.V. Vakhrushev, named after F. E. Dzerzhynsky, named after Kosmonauts, named after M.V. Frunze, "Rovenkivska"), the total yearly extraction of them at the beginning of the armed conflict accounted for about 20 million tons of rank "A" (anthracite) coal.

Coal extraction decline in Donetsk and Luhansk regions during 2013-2016 is quite significant and accounts for about 45 million tons, or about a quarter of total coal extraction on these regions in the pre-war period (Table). This situation in the coal industry endangers the steady functioning of electrical energy production, metallurgical and coke industries. In that period the reduction of production levels was observed at coal companies of any property form. However, at the state-owned enterprises the coal extraction had the stable trend of reduction with the most significant pace. The most significant decline was registered at SOE "Krasnolymanska" (practically by 4 times), SOE "Pervomaiskvuhillia" (by 3 times) and SOE "Selydivvuhillia" (close to by 3 times). At the same time coal extraction at SOE "Myrnohradvuhillia" did not change, in fact.

While at the beginning of the armed conflict the coal extraction reduction was caused by the losses of the significant industrial potential of total capacity of 18896,1 thousand tons per year at the uncontrolled territory, after the certain stabilization of the situation in 2015-2017 this was primarily the result of the Governmental policy of coal industry restructuring, containing the liquida- tion of unprofitable and rehabilitation of prospective enterprises with their further privatization. At the beginning of 2017, the loss of control over the several enterprises, producing "A"- rank coal, owned by PLC System Capital Management", was sensible by the consequences for the economies of the Eastern regions and Ukraine in whole; its total coal extraction in 2016 was more than 8 million tons.

The recovery of the economies of Donetsk and Luhansk regions in the conditions of visible changes in their industrial, economic and natural potentials requires first of all the estimation of the strategic importance of coal industry in the new economic and political conditions, finding of the role and position of coal industry in this process, as well as definition of its capacity of functioning in these conditions, alignment of strengths and competitive advantages, defining the opportunities of the sector's development in the rebuilding of Donbas economy, as well as analysis of limitations and factors, complicating the development of the coal industry.

The coal industry has been strategical for Ukraine's energy security. In the structure of the main fuel deposits, coal represents about $90 \%$; the deposits in significant extent are concentrated in Donbas. The activity of "basic" sectors of Donetsk and Luhansk regions' economies - metallurgical and coke and chemical industries - depends on the efficiency of coal industry; in the structure of industrial products sales of the regions these sectors accounted, respectively, for more than $50 \%$ and about $1 / 3$ in 2017. Thus, the issue of coal industry recovery is the issue of energy and economic security of Ukraine, and its solution requires the thorough analysis of any aspects of its functioning.

As the strength of coal industry in Donetsk and Luhansk regions' economy recovery, first of all, the presence at the controlled territories of the most prospective deposits of coal should be mentioned (towns of Pokrovsk, Dobropillia, Vuhledar). The coal mines, situated in these towns, are mainly "young", exploited for no more than 30 years; the significant part of them has been attributed as prospective ones, which allows realizing the technical retooling of the main production processes by the implementation of the equipment of new technical level. They own the prospective deposits of energetic and coke coal of gas-flame, coke, fat, gas rates with prevailing gas-flame and gas rates.

The prospects of coal industry development will strengthen the opportunities of new construction, reconstruction and technical reequipment of coal mines. This should be supported by the potential of the specialized construction organizations, which are at the territory controlled by Ukraine: PLC "Trest Artemshahtobud", PLC "Trest Krasnoarmiiskshahtobud", PLC SOE "Vuhlebud".

Taking into account the long history of industrial coal deposits processing in the Donbas, the development of coal industry of Donetsk and Luhansk regions is complicated by a number of limiting factors, conditioned by the ageing of the sector. The significant part of them contains unmanaged and poorly-managed factors. 
$\frac{8}{3}$

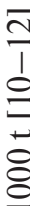

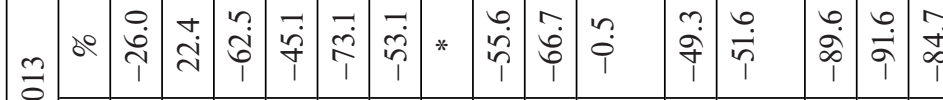

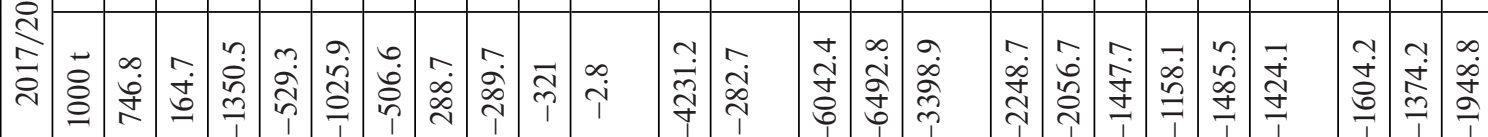

$\because$ ১0

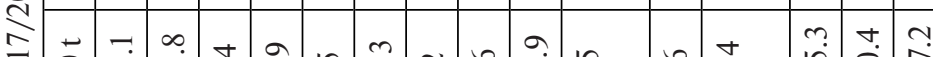

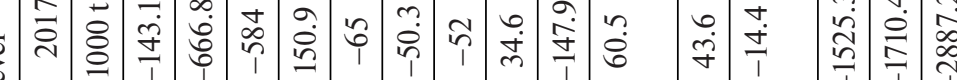

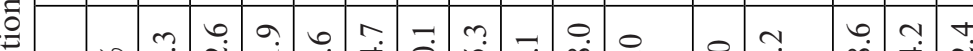

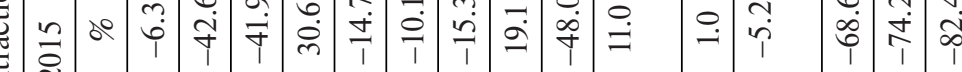

峁

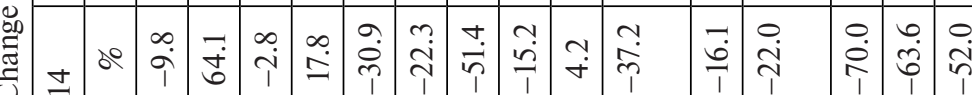

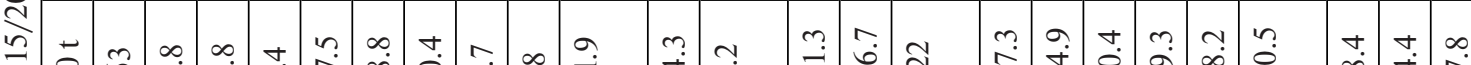

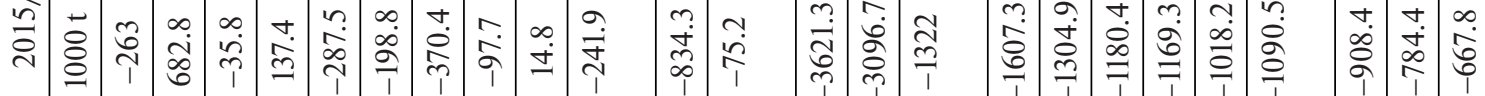

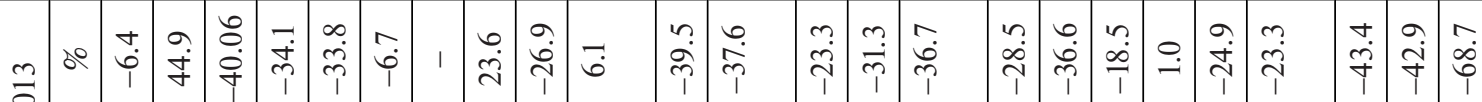

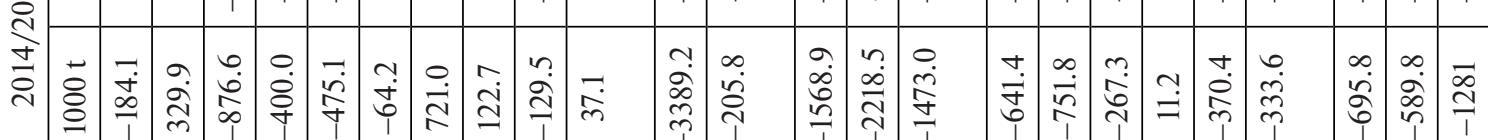

.0
0
0
0
0
0
0
0
0
0
0
0
0
0
0
0
0
0
0
0
0
0
0
0
0
0
0
0
0
0
0
0

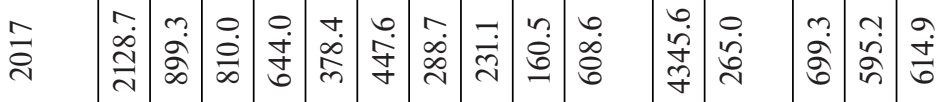

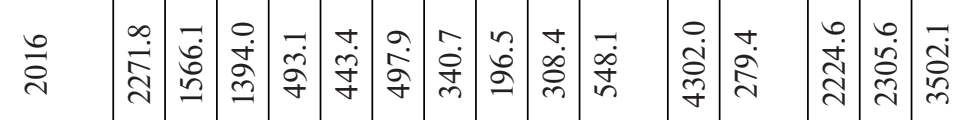

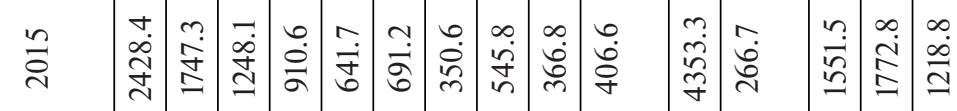

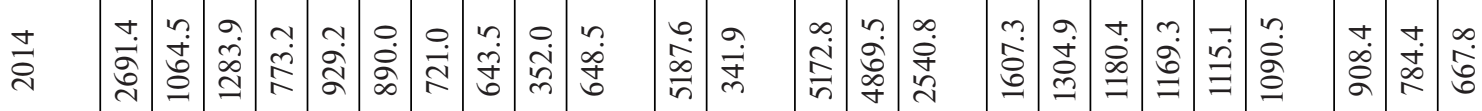

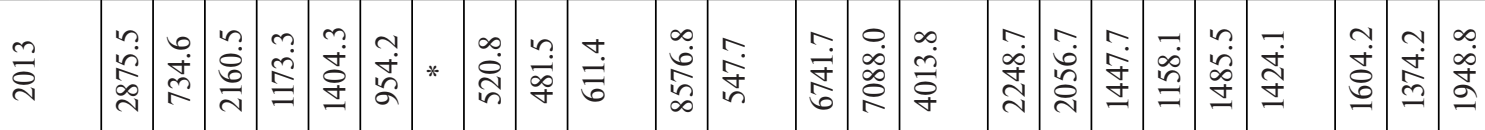

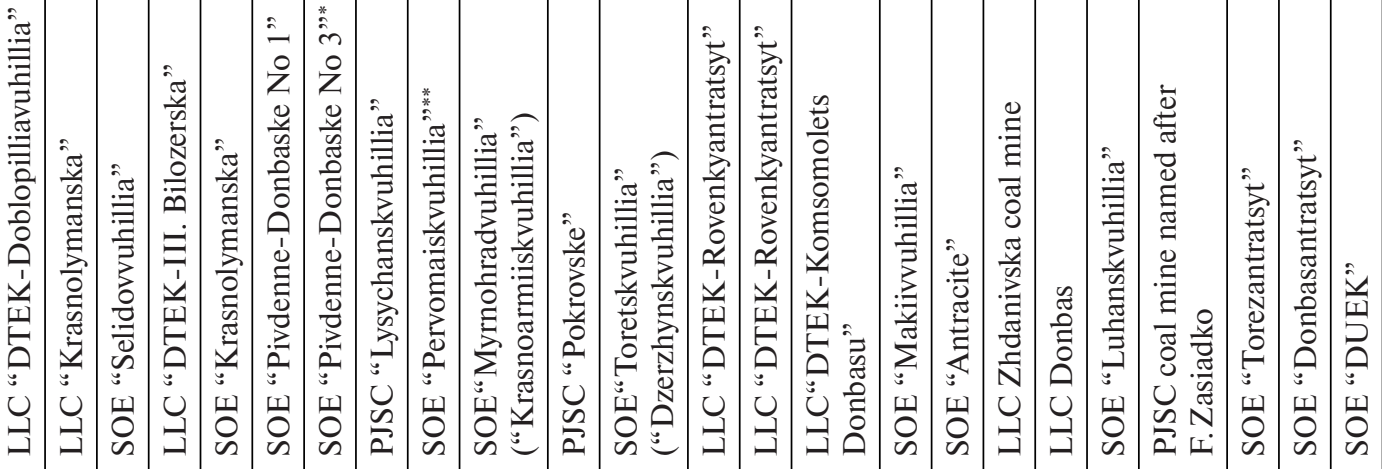




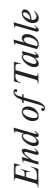

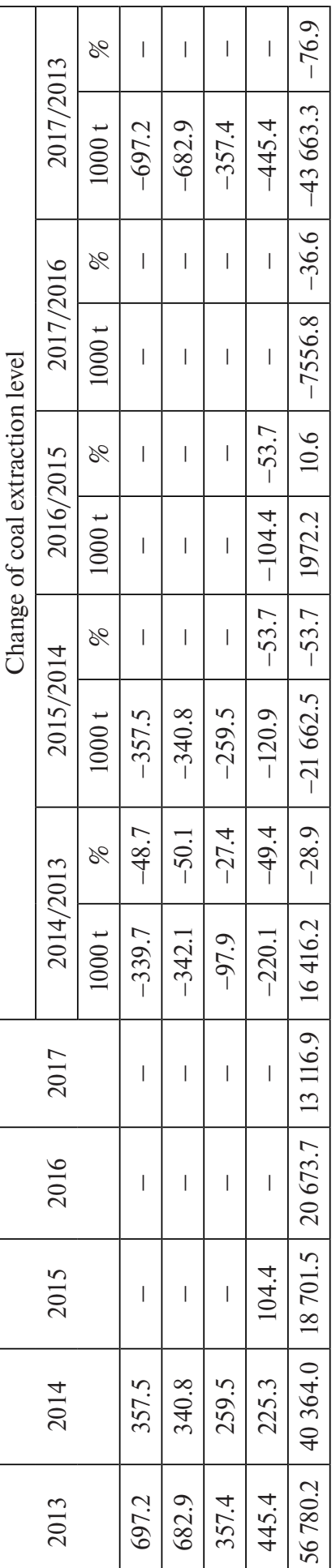

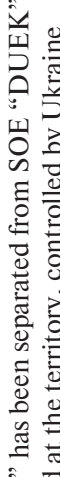

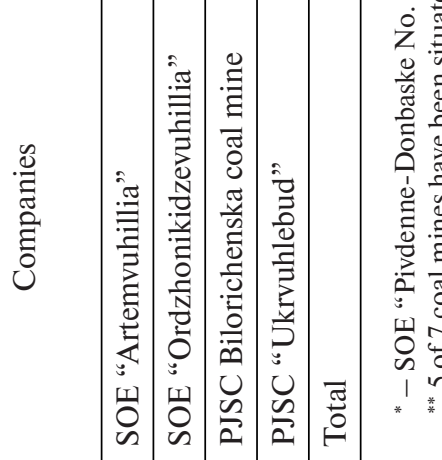


So, the complexity of mining-geological conditions of coal deposit development (significant depth of development and low density of coal, high risks of sudden coal and gas ejection, increasing of the number of coal mines in the group of overcategorical ones), as well as its possible deterioration during the restructuring of coal-extraction regions (increasing the flows of explosive gases in the structure) form the complicated and dangerous labor conditions tending steadily to negative changes. For now the world experience practices the termination of coal mines with the conditions, close to the conditions of minerals development in Donetsk and Luhansk regions.

In addition to the poorly-managed limiting factors of coal industry development, the problems should be added which are due to be regulated. Among them:

- incompleteness of market pricing mechanism for coal producers' products; shadow and illegal coal extraction; imperfect legal regulation of the sector, lack of financial resources for implementing governmental programs in coal industry;

- obsoleteness of the level of scientific and technical progress in the coal industry; low technical level of coal extraction, significant wearing of fixed assets (80-90\%), lack of financial resources for their renovation; insufficient extent and non-rational implementation of investments;

- invalid material and technical provision of the majority of coal mines (more than $95 \%$ of mines have been exploited without any reconstruction for over 20 years); termination of the terms of service of a significant part of coal extracting companies (50 years), which causes the deterioration of technical and economic performance of the enterprises, increases the requirement in their reconstruction;

- needs in subsidies for the coal industry; low efficiency of coal companies, high and growing costs of coal extraction;

- unmanageability of the factor of mining-geological condition deterioration due to implementation of scientific and technical progress.

The opportunities and efficiency of the sector's recovery during the rebuilding of Donetsk and Luhansk regions' economy recovery have been influenced by the factors, caused by the losses of the part of a specialized potential of the sector - enterprises providing the supportive technological processes and activities in coal industry. The significant number of organizations, providing capital works, reconstruction, technical reequipment and accident elimination at the coal mines, have been left at the uncontrolled territories, primarily in Donetsk: State JSC "Donetske SHPU (mine penetrating managing company)" of State holding "Spetsshakhtoobladnannia" (penetration of vertical shafts); Trust "Donetskshakhtoprokhodka" (works of shaft penetration and arming in complicated mining-geological conditions); mine rescue service (elimination of accidents and their consequences, rescue of people captured by accidents at coal mines); JSC "Shakhtspetsbud" (organization of mines construction, drilling and blasting operations, underground construction, reconstruction in heavy-complicated mining-geological conditions); JSC "Donbasshakhtobud" (construction, reconstruction and technical reequipment of coal mines).

The influence of weaknesses of the sector's development could be amplified due to the realization of a number of risks, the most probable of them are: absence (lack) of financing for coal enterprise reconstruction, especially those in state ownership; increase in costs of production preparation, caused by the changes in mining-geological conditions; deterioration of quality of extracted coal; further increase in coal cost; weakening of government regulation and control in the coal industry, especially in the period of restructuring and social reconversion of the regions with terminated mines; spreading of the shadow relations in coal industry, growth of illegal coal extraction; deepening of the contradiction between the importance of coal industry for national security of the country - and its technical and economic status; interest of certain business-elites in the development of coal industry still with shadow relations and obsolete trends in the exploitation of coal deposits; cheap workforce, ready to work in unsatisfactory and dangerous labor conditions, as well as low motivation of workers to change their qualification and re-train in accordance with the requirements of structural changes of the economy.

The opportunities of development of coal industry of Donetsk and Luhansk regions controlled by Ukraine have been further deteriorated by the situation at the global markets. The coal industry's functioning proceeds in Ukraine in the marks of global trends of energy market - shortening the consumption and price decline for fuel. These global market trends have been caused by the slow recovery of world economy since 2015-2016, the abundance of coal and hydrocarbon fuel (oil, gas), the development of the markets of renewable energy and active implementation of energy saving technologies, especially in the industrial sector.

In addition, the global goals of sustainable growthbased development put certain requirements to overcome the extensive type of development of Donetsk and Luhansk regions, which, due to coal industry priorities, permanently decreases the balance stocks of coal and influences negatively the environmental situation in the region.

Following the growth of the global economy in 2017, the International Monetary Fund (IMF) expected the further growth of global economy by $3.9 \%$ and demand recovery in many large countries - raw materials producers [13]. However, this will not improve significantly the situation in the coal segment of the energy sector of Ukraine. Although the global coal consumption, according to the forecasts of the International Energy Agency, will grow, in the next five years this growth will slow down [14].

Given the fact that energetic coal segment remains dominating at the controlled territories of Donetsk and Luhansk regions, the sector has been weakened by the increase in competition at the global markets of energetic coal (especially from South Africa) and by the lack of business interest growth in the energetic coal market 
in Europe as a consequence of the economic recession, as well as due to the stimulation of transfer from the traditional coal energy to using renewable energy sources. In the view of Ukraine's integration into European energy space, this is the factor, strongly deteriorating the opportunities of the sector development in the new conditions. Additionally, coal loses the role of the main energy resource, and the shift from the traditional coal energy production to the renewable sources usage causes the small probability of steady demand for energetic coal in the external markets in the future.

The competitive advantages of coal industry should be formed only by the implementation of radical solutions, aimed to change the access to coal energy sources, or by the implementation of the new industrial technologies of coal deep processing and more efficient usage.

Recently the idea has got widespread of the implementation of the technology of underground coal gasification, aimed to abandon the direct coal extraction and based on the technological conditions for coal transformation into gas directly underground and transportation of the gas to the surface. The opportunities and perspectives of this technology implementation at the territories of Donetsk and Luhansk regions have been proved by the Memorandum of interaction between Ukraine and Australia concerning the co-operation in underground coal gasification in Ukraine, signed on 27.07.2015.

The prospective decline of demand for energetic coal in the global markets requires the rethinking of the opportunities of realization of the technological changes in Ukraine (in Donetsk and Lugansk regions in particular) for deeper processing of raw materials and coal processing waste products after coal dressing and coke and chemical production.

In the process of searching the ways of reduction of the dependence of the national economy on natural gas, the energetic coal market can get the new impulse for development at the basis of implementing new technologies. According to the estimates of Ukrainian and Chinese experts, the realization of the projects of productive assets construction for synthetic gas production could give the opportunity to reduce natural gas purchases to 4 billion $\mathrm{m}^{3}$ yearly, to ensure the sales of domestic coal and should favor the creation of about 5000 new working places [15]. Namely, the construction of the plants of synthetic gas production from domestic coal will support the coal market in Ukraine in the medium-term perspective with the further orientation on the settlement of alternative energy market. In addition, this approach will favor the elaboration of the new domestic cheaper industrial technologies of deeper coal procession.

The significant step in the solving of the problems of coal industry recovery in Donetsk and Luhansk regions, negatively influencing its development, is the adoption of the Energy Strategy of Ukraine for the period till 2035 "Security, energy efficiency, competitiveness" by the Cabinet of Ministers' Directive No. 605-p from August 18,2017 ; there the coal industry is determined as the basis for the development of competitive economy, nation- al security and energy independence of Ukraine [16]. The adoption of the Strategy strengthens the opportunities of recovery of the coal industry of Donetsk and Luhansk regions as one of the basic sectors of their economies on the basis of neo-industrialization and orientation on technical and technological re-equipment of key companies of the coal industry.

Meanwhile, it is worth mentioning that the recovery of coal industry of Donetsk and Luhansk regions is going on in the conditions of investment activity reduction in the coal industry and low investment attractiveness of coal industry companies, representing the global trend of investors' demotivation in old industries development. This complicates the recovery of the coal industry on the basis of efficiency improvement of coal companies.

The restructuring of the coal industry of Donetsk and Luhansk regions, prescribed by the Energy Strategy of Ukraine, has been realized in the framework of general changes of energy sector of Ukraine and takes into account the global trends of reduction of the share of mineral fuel in energy balance. This approach determines the general features of coal industry development by means of the following actions:

- distinction of the prospective coal mines, projected to be left in the property of the Ministry of Energy and Coal Industry. Among them: 5 enterprises of Donetsk region ("1/3 Novohrodivska", Coal mine named after Surhai, "Pidvenno-Donbaska No. 1", Coal mine named after Stakhanov, "Rosiia") and one enterprise of Luhansk region (Coal mine named after Melnykov). These enterprises, together with two enterprises of the Lviv-Volyn coal basin, are projected to be used to ensure the energy independence of the country on the basis of technical re-equipment, modernization and improvement of labor protection, as well as optimization of the structure of separated units of National Coal company (creation of project and research center and service and technical center to support and repair the equipment, liquidation of non-profile assets;

- selection of coal mines for privatization. Among the coal enterprises of Donetsk and Luhansk regions there have been selected 9 coal mines projected to be privatized after reaching the breakeven level. These are the coal mines: "Krasnolymanska", "Tsentralna", "Ukraiina”, "Kurakhivska”, Coal mine named after Dzerzhynskyi, "Toretska” (Donetsk region), "Horska”, "Karbonit", named after Kapustin (Luhansk region);

- selection of coal mines for abandonment by the reason of their bad unprofitability. Among the enterprises of Donetsk and Luhansk regions 7 have been selected to be abandoned or conserved, namely: Coal mine "Rodynska" of SOE "Krasnoarmiiskvuhillia"; Coal mine "Pivnichna" and Coal mine "Pivdenna" of SOE "Dzerzhynskvuhillia”, Coal mine named after G. Dymytrov of SOE "Krasnoarmiiskvuhillia" (Donetsk region), Coal mine "Zolote" and Coal mine "Toshkivska" of SOE "Pervomaiskvuhillia", Coal mine "Novodruzheska" and Coal mine "Pryvolnianska" of SOE "Lysychanskvuhillia" (Luhansk region) [17].

The Strategy does not only settle the basis of coal industry reforms, but also defines the possible vector of 
structural reconstruction of the economies of Donetsk and Luhansk regions based on the re-equipment of power units of thermal power plants from anthracite to gas of coal and due to the planned refuse from shortly supplied "A"-range coal. For Donetsk and Luhansk regions this means the strengthening of the competitive positions of coal enterprises at the controlled territory, extracting, prevalently, gas-range coal. Also, this is the additional incentive for the development of machinebuilding of the region.

The definite strategic position concerning the sector, declared process of its restructuring using the European experience of mitigation of social and environmental consequences, as well as the social reconversion of the regions of terminated coal mines according to the best European practices significantly strengthens the opportunities of coal industry recovery on the basis of maximization of efficiency of production for Ukraine's domestic requirements.

However, the performance of public management in the sphere of the recovery of coal industry of Donetsk and Luhansk regions has been significantly influenced by the risk of the lack of realization of positions, declared by the Energy Strategy of Ukraine. These risks have been strengthened by:

- the absence (as for 01.02.2018) of the action plan for the realization of Energy Strategy (has been revised by the Ministry of Energy and Coal Industry of Ukraine);

- the lack of full realization of Action plan for the realization of the Concept of the reforming and development of the coal industry for the period till 2020: as for 01.02.2018 the Complex Program of coal enterprises' operation for the period till 2020 has not been elaborated, as planned.

Conclusions. Thus, the efficient functioning of the coal industry of Donetsk and Luhansk regions in the new economic and political conditions is possible and requires:

- restructuring based on the definite legal regulation of these problems and precise following of the goals of the Energy Strategy of Ukraine;

- considering the previous experience of coal industry restructuring, obligatory complementation of the sector restructuring with the complex of measures to mitigate the social and economic consequences and social reconversion of the regions of coal mines termination, ensuring the high manageability of the processes of saving the human potential of the coal industry and its inclusion into the new types of economic activity;

- starting the realization of the structural changes in the coal industry of Ukraine (Donetsk and Luhansk regions, in particular) based on the implementation of modern technologies in the energy sector, favoring the structural reconstruction of the economies of all oldindustrial regions of Ukraine.

\section{Reference.}

1. Starychenko, L. L. and Fokina, I. V., 2014. Institutionalization of market infrastructure of coal industry. In: Strategy and mechanisms of industrial development regulation: Working papers. Kyiv, NAS of Ukraine, Institute for Economics of Industry, pp. 168-189.

2. Starychenko, L. L., Cherevatskyi, D. Yu. and Chejlyax, D.D., 2014. On the spreading of market relations in the coal industry of Ukraine. The Coal of Ukraine, 10, pp. 12-17.

3. Snihova, O. Yu., 2006. The mechanism of problems solving of depressive regions, conditioned by the restructuring of coal industry: analytical notes. The $\mathrm{Na}$ tional Institute for Strategic Studies [online]. Available at: $<$ http://old.niss.gov.ua/Monitor/Monitor_33/03. htm\#a1> [Accessed 5 February 2018].

4. Bobro, D. G. Coal industry of Ukraine in the conditions of hybrid war: analytical notes, The National Institute for Strategic Studies, No 24, Series «National Security» [online]. Available at: <http://www.niss.gov.ua/articles/1890/> [Accessed 7 December 2017].

5. Gonchar, M., Chubik, A. and Ishhuk, O., 2014. Hybrid war in the Eastern Europe. Non-military dimension. Energetic component: Analytical report. Kyiv: Center of Globalistics [online]. Available at: <http://geostrategy. org.ua $>$ [Accessed 11 October 2017].

6. Libanova, E. M., Amosha, O. I. and Vyshnevskyi, V. P., 2015. Revival of Donbas: the estimates of socio-economic losses and priority directions of state policy. Kyiv, The National Academy of Science of Ukraine [pdf]. Available at: <http://ief.org.ua/wp-content/uploads/2015/10/ Стратегія-Відновлення-Донбасу-16.10.pdf> [Асcessed 22 September 2017].

7. Amosha, O.I., Bulyeyev, I.P. and Briukhovetska, N.Yu., 2016. The industry of Donetsk and Lugansk regions: the problems of further functioning and recovery: scientific and analytical report. Kyiv: NAS of Ukraine, Institute for the Economics of Industry.

8. Snihova, O. Yu., 2016. Risks and opportunities of coal industry development of Donetsk and Luhansk regions in the recovery of the economy of the East of Ukraine. The Herald of Economics Science of Ukraine, 2, pp. 170-174.

9. The current state of enterprises of coal industry, 2018 [online]. Available at: <http://mpe.kmu.gov.ua/minugol/control/uk/publish/article?art_id=244964062\& cat_id=244930831 > [Accessed 9 January 2018].

10. UA energy, 2018. Coal mining in Ukraine decreased by $14.6 \%$ in 2017 [online]. Available at: <http://uaenergy.com.ua/post/30399/dobycha-uglya-v-ukraine-v2017-g-snizilas-na/> [Accessed 15 September 2018].

11. UA energy, 2015. Coal mining in Ukraine decreased twice in January, 2015 [online]. Available at: <http:// uaenergy.com.ua/post/21337/dobycha-uglya-v-yanvare-2015-g-upala-v-2/http://uaenergy.com.ua/post/ 30399/dobycha-uglya-v-ukraine-v-2017-g-snizilasna/> [Accessed 15 September 2018].

12. UA energy, 2016. Coal mining in Ukraine decreased by $38.8 \%$ within 12 months 2015 [online]. Available at: $<$ http://uaenergy.com.ua/post/24502/dobycha-uglyav-ukraine-za-12-mes-2015-g-upala-na/http://uaenergy.com.ua/post/30399/dobycha-uglya-v-ukraine-v2017-g-snizilas-na/> [Accessed 15 September 2018].

13. International Monetary Fund, 2017. World Economic Outlook [online]. Available at: <http://www.imf.org/en/ Publications/WEO/Issues/2017/09/19/world-economic-outlook-october-2017> [Accessed 15 February 2018]. 14. International Energy Agency, 2017. World Energy Outlook [online]. Available at: <https://www.iea.org/ weo2017/> [Accessed 9 December 2017]. 
15. Ukraine reminded to $P R C$ about the credit for building the plants for coal gasification, 2015 [online]. Available at: <http://rian.com.ua/economy/20150128/ 362697054.html $>$ [Accessed 25 August 2017].

16. Government Portal, 2017. On the adoption of the Energy Strategy of Ukraine for the period till 2035 "Security, energy efficiency, competitiveness". The Directive of Cabinet of Ministers of Ukraine from August 18, 2017 No 605-p [online]. Available at: <https://www.kmu.gov.ua/ua/ npas/250250456> [Accessed 29 January 2018].

17. Legislation of Ukraine, 2017. The Concept on reforming and development of coal industry for the period till 2020. Adopted by the Directive of Cabinet of Ministers of Ukraine from May 24, 2017 No 733-p [online]. Available at: <http://zakon3.rada.gov.ua/laws/show/733-2017-\% D1\%80> [Accessed 3 July 2017].

\section{Перспективи відновлення ефективного функціонування вугільної галузі сходу України}

\section{О. Ю. Снігова}

Державна установа „Інститут економіки та прогнозування НАН України“, м. Київ, Україна, e-mail: osnigova @ukr.net

Мета. Встановлення можливостей і перспектив відновлення вугільної промисловості підконтрольних територій Донецької та Луганської областей в сучасних економічних і політичних умовах. Визначення ролі цієї території у відновленні економіки східних регіонів України.

Методика. Мета реалізована на підставі використання наступних методів: узагальнень і системного аналізу 3 використанням комплексного та міждисциплінарного підходів - при визначенні зовнішніх і внутрішніх чинників, що формують можливості, ризики та загрози для функціонування вугільної промисловості в сучасних умовах; SWOTаналізу - при оцінюванні сильних і слабких сторін вугільної промисловості підконтрольних територій Донецької та Луганської областей у нових економічних і політичних умовах.

Результати. Оцінені сильні та слабкі сторони вугільної промисловості підконтрольних територій Донецької та Луганської областей, визначені можливості й ризики іiі функціонування, а також встановлені перспективи розвитку вугільної галузі цих областей у нових економічних і політичних умовах.

Наукова новизна. Полягає у визначенні спроможності та перспектив відновлення вугільної галузі Донецької та Луганської областей у нових економічних і політичних умовах, що характеризуються втратою частини потенціалів східних областей і входження України до європейського енергетичного простору.

Практична значимість. Результати дослідження можуть бути використані органами державної влади для формування й реалізації концепцій, стратегій, програм і планів заходів з їх реалізації при забезпечені відновлення економіки східних регіонів України в умовах змін економічного, промислового та природного потенціалів Донецької та Луганської областей.
Ключові слова: вугільна промисловість, перспективи відновлення, підконтрольні території, Донецька та Луганська області, ризики, можливості, європейський енергетичний простір

\section{Перспективы восстановления эффективного функщионирования угольной отрасли востока Украины}

\section{Е. Ю. Снеговая}

Государственное учреждение „Институт экономики и прогнозирования НАН Украины“, г. Киев, Украина, e-mail: osnigova @ukr.net

Цель. Определение возможностей и перспектив восстановления угольной промышленности подконтрольных территорий Донецкой и Луганской областей в современных экономических и политических условиях. Определение роли этой отрасли в восстановлении экономики восточных регионов Украины.

Методика. Цель реализована на основе использования следующих методов: обобщений и системного анализа с использованием комплексного и междисциплинарного подходов - при определении внешних и внутренних факторов, которые формируют возможности, риски и угрозы для функционирования угольной промышленности в современных условиях; SWOT-анализа - при оценке сильных и слабых сторон угольной промышленности подконтрольных территорий Донецкой и Луганской областей в новых экономических и политических условиях.

Результаты. Определены сильные и слабые стороны угольной промышленности подконтрольных территорий Донецкой и Луганской областей, определены возможности и риски ее функционирования, а также установлены перспективы развития угольной отрасли этих областей в новых экономических и политических условиях.

Научная новизна. Заключается в определении способности и перспектив восстановления угольной отрасли Донецкой и Луганской областей в новых экономических и политических условиях, характеризующихся потерей части потенциалов восточных областей и интеграция Украины в европейское энергетическое пространство.

Практическая значимость. Результаты исследования могут быть использованы органами государственной власти для формирования и реализации концепций, стратегий, программ и планов мероприятий по их реализации при обеспечении восстановления экономики восточных регионов Украины в условиях изменений экономического, промышленного и природного потенциалов Донецкой и Луганской областей.

Ключевые слова: угольная промышленность, перспективы восстановления, Донецкая и Луганская области, риски, возможности, европейское энергетическое пространство

Рекомендовано до публікації докт. екон. наук В. І. Ляшенком. Дата надходження рукопису 05.01.18. 